\title{
Relationship between element concentrations and body size in the Lake Maggiore population of Unio pictorum mancus (Mollusca, Bivalvia)
}

\author{
Gian Maria BEONE*, Ilenia CATTANI, Maria Chiara FONTANELLA and Oscar RAVERA ${ }^{1)}$ \\ Università Cattolica del Sacro Cuore, Istituto di Chimica Agraria e Ambientale, Via E. Parmense 84, 29122 Piacenza, Italy \\ ${ }^{1)} \mathrm{CNR}$ - Institute of Ecosystem Study, Largo Tonolli 50, I - 28922 Verbania Pallanza, Italy \\ *e-mail corresponding author: gian.beone@unicatt.it
}

\begin{abstract}
The study focused on using a fresh-water mussel (Unio pictorum mancus) as a bioindicator of various pollutants, and particularly metals. The elements considered were: $\mathrm{Al}, \mathrm{As}, \mathrm{Ca}, \mathrm{Cd}, \mathrm{Co}, \mathrm{Cr}, \mathrm{Cu}, \mathrm{Fe}, \mathrm{Mn}, \mathrm{Mo}, \mathrm{Ni}, \mathrm{Pb}, \mathrm{V}$ and $\mathrm{Zn}$. This research was carried out at a site where various other studies have been conducted on important characteristics of the same population of Unio. This site is a small bay called "Sabbie d'Oro" located on the south-east coast of Lake Maggiore. Our study involved quantifying the capacity of this mollusc to concentrate large amounts of metal in its body without evident consequences by using detoxification mechanisms. We analysed not only element concentrations, but also their variability (expressed as CV\%) in the soft tissues and in the shell, for two main reasons: i) the sampling design should include a preliminary analysis to determine how many specimens is necessary collect to ensure a specified level of precision; ii) the sample variability value may be combined with the value of analytical precision (BCR) to obtain an estimate of the "experimental" precision. In soft tissue, Ca accumulation tended to increase with size, and Al accumulation decreased with size. In shell, Ca and Ni were stored more than in soft tissue, but not proportionally to size. V, Cr and Mo tended to accumulate in the shell progressively over the years, whereas Co and Al are "diluted" during growth, or are absorbed mainly during the juvenile stage. Partition between shell and soft tissue resulted roughly the same in the juvenile and adult stages for the following elements: $\mathrm{Fe}, \mathrm{Al}, \mathrm{Co}, \mathrm{As}, \mathrm{Pb}$. The relationships among the various elements were schematized in a hierarchical tree plot.
\end{abstract}

Key words: freshwater mussel, metals, shell size, bioindicators

\section{INTRODUCTION}

Pollutants in freshwater can originate from a variety of sources, including municipalities, agriculture, construction, industry and atmospheric depositions. Once in the water column, trace element inputs are removed via sediment deposition, complexation by dissolved organic carbon (DOC) (Swift 1989) or uptake and accumulation in aquatic organisms (Adriano 2001). Aquatic organisms can be grouped into two categories based on their uptake of pollutants: excluders (low uptake) and accumulators (extreme uptake). Accumulators, such as bivalve molluscs, possess a detoxification system based on sequestration and tend to show elevated concentrations of metals even in less contaminated environments (Mason \& Jenkins 1995). Mussels accumulate many metals from the water they filter, without discriminating between essential and non-essential elements. In fact, they are exceptionally resistant to toxicity as a result of a variety of detoxification mechanisms, such as the production of metal-binding thyoneins or calcium phosphate granules (Ravera et al. 2003a). For this and many other reasons (e.g., abundance in many terrestrial and aquatic ecosystems, easy availability for collection, sedentary way of life and ability of several species to survive in both clean and polluted waters), unionidae have long been regarded as useful bioindicators (Boy- den 1977; Lau et al. 1998; Gundacker 2000; Ravera et al. 2007a). Accumulation follows different pathways in the shell and in the soft tissues of the mussel producing different chemical compositions, with different turnover times (much shorter in the soft tissues). As a consequence, the chemical composition of the soft tissues may be considered an indicator of the most recent environmental conditions, whereas the shell composition represents the average conditions from the birth of the mussel up to the moment the sample was collected (Ravera et al. 2007b). Because the ring number corresponds approximately to the age of the mussel (Grefsurd et al. 2006), shell analysis can be used to obtain valuable information on water characteristics (pollutants, trophic level and physical conditions such as temperature and $\mathrm{pH}$ ) (Ravera et al. 2007b) for a well-defined past period, which is impossible or very difficult to achieve by water sampling (in terms of time and money). In a previous study, Metcalfe-Smith et al. (1996) highlighted the fact that seasonal cycles, the physical environment and the biological state of the organisms strongly influence data variability when this monitoring method is used. This research deals with a species of mussel (Unio pictorum mancus) which is particularly suitable as an indicator of trace metal abundance thanks to its capacity to accumulate trace pollutants from the surrounding environment, its colonization of aquatic environments ranging from oligotrophic to 
hypertrophic, and its availability in all seasons. The specimens were collected from a site on the oligomesotrophic Lake Maggiore. Soon after collection, the mussels were divided into various size-classes. $\mathrm{Zn}, \mathrm{Fe}$, $\mathrm{Mn}, \mathrm{Cu}, \mathrm{Al}, \mathrm{V}, \mathrm{Cr}, \mathrm{Co}, \mathrm{Ni}, \mathrm{As}, \mathrm{Mo}, \mathrm{Cd}$ and $\mathrm{Pb}$, which are essential or non-essential for mussels in relation to their concentration (Nielsen 2000; Ravera et al. 2003a), were measured in the soft tissues and shells along with $\mathrm{Ca}$, which plays an important role in detoxifying soft parts (Markich et al. 2001) and is very abundant in the shell. Following a hypothesis described in previous works (Beone \& Ravera 2003; Ravera et al. 2003a, 2003b, 2005, 2007a, 2007b), the objective of this study was to determine the advantages of using Unio pictorum as biomonitor for heavy metal pollution in freshwater ecosystems.

\section{MATERIALS AND METHODS}

\subsection{Sampling site}

The mussel were all collected from one only station, located on the south-eastern side of the deep oligomesotrophic Lake Maggiore (Tab. 1), in a location called Sabbie d'Oro, which is a gently sloping bay with silty-muddy sediments and very active water renewal attributable to wave action (latitude N 45 $50^{\prime} 19^{\prime \prime}$, longitude E 8³7'17"; Fig. 1).

Tab. 1. Morphometric parameters of Lake Maggiore (Ambrosetti et al. 1992).

\begin{tabular}{lc}
\hline Altitude $(\mathrm{m}$ a.s.1.) & 194 \\
Watershed area $\left(\mathrm{km}^{2}\right)$ & 6599 \\
Lake area $\left(\mathrm{km}^{2}\right)$ & 212.5 \\
Mean depth $(\mathrm{m})$ & 177 \\
Maximum depth $(\mathrm{m})$ & 370 \\
\hline
\end{tabular}

\subsection{Mussel sampling and preparation}

We selected Painter's mussel, Unio pictorum subspecies mancus (Bivalve, Unionidae), and tested its usefulness as an indicator of trace elements in the environment (Beone \& Ravera 2003; Ravera et al. 2003a, b, 2005, 2007a, b). In July 2002, we randomly collected 37 adult stage mussels by hand from the littoral zone of Lake Maggiore, and preserved them in plastic bags in an ice-box for transportation to the laboratory. Even if a single sampling period, combined with one only sampling station, cannot be considered representative of the ecological situation in the littoral zone of the entire lake, this choice represents an attempt to remove any influence of trophic level, population density, seasonal variation of biomass and bioaccumulation (Ravera et al. $2007 a, b)$, because our objective was to focus differences between various sizes and age groups in a single population of one sub-species.

The mussels were collected in summer because in this period the growth is at its maximum after the growth interruption that occurs in winter (Negus 1966). We assumed that the number of the growth rings in the shell corresponds to the individual age expressed in years.

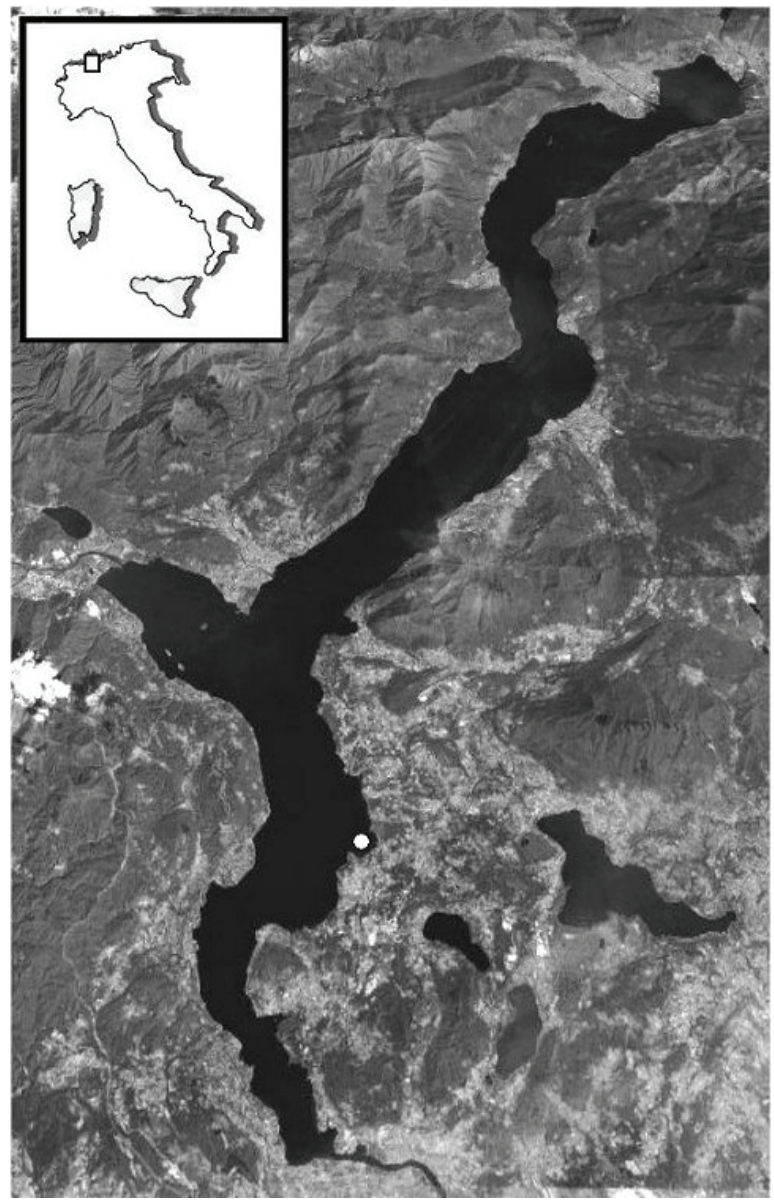

Fig. 1. Sampling station on Lake Maggiore (white spot).

Age was determined by counting the annual rings in the shell, although this becomes more difficult for adults older than 3 years, like the specimens in our study, and can result in a margin of error of approximately 1-2 years because the more recent rings are concentrated in a small space on the shell (Ravera \& Sprocati 1997). Determining age using the annual rings in the ligament raises similar objections. A more reliable method involves examining thin sections (Kilada et al. 2007), but it can only be applied to a small number of specimens, because a specialized technician is required. Once in the lab, shell length, width and thickness were measured using a calliper, while ring number was obtained from the most frequent of the estimates realized independently by three scientists. An additional class of specimens (9), corresponding to the juvenile stage (characterized by the absence of rings and the presence of a protoconch), was collected in September 2003, despite the difficulties resulting from their small size and burrowing way of life (Patzner \& Müller 2001). The month of September was chosen because it was suitable for collecting samples at the juvenile stage. Unio has a 
Tab. 2. Means of metal concentrations in shell and mussel of the 43 samples under investigation and in BCR (Community Bureau of Reference) mussel tissue CRM 278. Values found in certified sample are means of 11 replicates (different amounts analysed repeatedly) $\pm \mathrm{SD}$ for $\mathrm{Zn}, \mathrm{Fe}, \mathrm{Mn}, \mathrm{Ca}, \mathrm{Cu}$ and $\mathrm{Al}$, and of 19 replicates (different amounts analysed repeatedly) $\pm \mathrm{SD}$ for $\mathrm{V}, \mathrm{Cr}$, $\mathrm{Co}, \mathrm{Ni}, \mathrm{As}, \mathrm{Mo}, \mathrm{Cd}$ and $\mathrm{Pb}$. Values in brackets are reported by $\mathrm{BCR}$ and are indicative only.

\begin{tabular}{ccccc}
\hline Element & $\begin{array}{c}\text { Found } \\
\left(\mu \mathrm{g} \mathrm{g}^{-1}\right)\end{array}$ & $\begin{array}{c}\text { Certified } \\
\left(\mu \mathrm{g} \mathrm{g}^{-1}\right)\end{array}$ & $\begin{array}{c}\text { Shell } \\
\left(\mu \mathrm{g} \mathrm{g}^{-1}\right)\end{array}$ & $\begin{array}{c}\text { Mussel } \\
\left(\mu \mathrm{g} \mathrm{g}^{-1}\right)\end{array}$ \\
\hline $\mathrm{Ca}$ & $981 \pm 50$ & 1000 & 368000 & 53900 \\
$\mathrm{Cu}$ & $9.5 \pm 0.4$ & $9.6 \pm 0.2$ & 5.1 & 34 \\
$\mathrm{Fe}$ & $128 \pm 6$ & $133 \pm 4$ & 57 & 1600 \\
$\mathrm{Mn}$ & $6.9 \pm 0.6$ & $7.3 \pm 0.2$ & 210 & 4880 \\
$\mathrm{Zn}$ & $73 \pm 2$ & $76 \pm 2$ & n.d. & 631 \\
$\mathrm{Al}$ & $39 \pm 7$ & & 40 & 237 \\
$\mathrm{~V}$ & $0.54 \pm 0.07$ & & 0.04 & 0.60 \\
$\mathrm{Cr}$ & $0.94 \pm 0.09$ & $0.80 \pm 0.08$ & 0.87 & 4.27 \\
$\mathrm{Co}$ & $0.34 \pm 0.03$ & $(0.34)$ & 0.49 & 0.80 \\
$\mathrm{Ni}$ & $1.1 \pm 0.1$ & $(1.0)$ & 10.7 & 6.1 \\
$\mathrm{As}$ & $5.7 \pm 0.2$ & $5.9 \pm 0.2$ & 0.22 & 8.2 \\
$\mathrm{Mo}$ & $0.37 \pm 0.05$ & & 0.02 & 0.66 \\
$\mathrm{Cd}$ & $0.32 \pm 0.03$ & $0.35 \pm 0.07$ & 0.04 & 2.09 \\
$\mathrm{~Pb}$ & $1.89 \pm 0.18$ & $1.91 \pm 0.04$ & 5.92 & 0.30 \\
\hline
\end{tabular}

short breeding season, from April to mid-August, and the glochidia (larval stage) are released from a marsupium as soon as they are mature. Glochidia are generally species-specific and attach to fish for two to five weeks (depending on temperature), forming a cyst on the external surface of the fish. After completing their development in this parasitic stage, they break free from the host, and drop to the bottom of the lake to begin an independent life (Bauer \& Wächtler 2001).

We obtained 9 shells with no rings and 4, 10, 14 and 7 shells characterized by 3, 4, 5 and 6 rings respectively. Individuals with 7 rings were two only and were consequently excluded. Shells with 3 or more rings were measured and afterwards divided into three length classes with the same width: $51-58 \mathrm{~mm}, 58.5-65.5 \mathrm{~mm}$ and $66-73 \mathrm{~mm}$, each one containing 9 individuals at least. To avoid any loss of trace elements in the samples, the mussels were not permitted to discharge undigested materials in clean water, and the soft tissues were separated from the shells. The soft tissues of each specimen were weighed and frozen at $-20{ }^{\circ} \mathrm{C}$ until analysis. Before analysis, the soft tissues of the mussels were freeze-dried, kept at $40{ }^{\circ} \mathrm{C}$ for 24 hours and then pulverised using a Planetary Micro Mill with agate bowl and balls. The shells were broken up before pulverisation. The powders were passed through a $0.2 \mathrm{~mm}$ sieve and mineralised in a CEM MDS-2000 a Microwave Digestion System (Mattews, NC, USA) using $\mathrm{HNO}_{3}(65 \%$ $\mathrm{w} / \mathrm{v})$ and $\mathrm{H}_{2} \mathrm{O}_{2}(30 \% \mathrm{w} / \mathrm{v})$ at $180{ }^{\circ} \mathrm{C}$.

\subsection{Sample analysis and instrumentation, precision and trueness}

The nitric acid $(65 \% \mathrm{w} / \mathrm{v})$ was purified using a subboiling system (Milestone mod. SubPURE) and hydrogen peroxide $(30 \% \mathrm{w} / \mathrm{v})$ was Suprapur reagent (Merck, Darmstadt, FRG). High purity water was produced using a Milli-QTM deionizing system (Millipore, Bedford, MA, USA). The solution obtained from acid digestion was filtered before analysis. $\mathrm{Zn}, \mathrm{Fe}, \mathrm{Mn}, \mathrm{Ca}$, $\mathrm{Cu}$ and $\mathrm{Al}$ were measured via Inductively Coupled Plasma Optical Emission Spectrometry (ICP-OES Perkin Elmer mod. Optima 2100 DV), while V, Cr, Co, $\mathrm{Ni}, \mathrm{As}, \mathrm{Mo}, \mathrm{Cd}$ and $\mathrm{Pb}$ (which are commonly present at trace level concentrations) were measured via Inductively Coupled Plasma-Mass Spectrometry (ICP-MS Agilent 7500 ce). Calibration for each ICP was obtained using external standards. Standard solutions of each element investigated were prepared by diluting a 100 $\mathrm{mg} \mathrm{L}^{-1}$ multielement solution obtained from CPI International with the same amount of acid used to dissolve the samples. Glassware was cleaned by soaking with the contact overnight in a $10 \%(\mathrm{w} / \mathrm{v})$ nitric acid solution and then rinsed with deionized water. Analytical precision and trueness were checked by using Certified Reference Material of Mytilus edulis (mussel tissue BCR 278) and conducting repeated analyses of different amounts of it (Tab. 2). The recovery rate for the certified elements always ranged between 80 and $120 \%$. Quality control gave good precision $(\mathrm{SD}<10 \%)$ in almost all samples.

\subsection{Statistics}

We adopted the coefficient of variation $(\mathrm{CV} \%)$ to test the significance of the variability of elements concentrated in the shell and soft tissues. This approach allowed to compare datasets with different units or widely different means. Paired comparisons of variability between age or size groups were realized by Wicoxon signed rank test, by examining the ranking of elements by each age or size group. Level of statistical significance was set at 0.05 .

Statistical analysis of the results was performed using SAS System (S.A.S. Institute 1996). A hierarchi- 
Tab. 3. Coefficient of variation ( $\% \mathrm{CV})$ calculated from mean and standard deviation of 9 measurements at least, for each element quantified in BCR (Community Bureau of Reference) mussel tissue CRM 278 and mussel shell and tissue samples. Unio pictorum mancus samples were divided into size classes (juvenile stage, 51-58 $\mathrm{mm}, 58.5-65.5 \mathrm{~mm}$ and $66-$ $73 \mathrm{~mm}) . *$ values not detectable.

\begin{tabular}{|c|c|c|c|c|c|c|c|c|c|}
\hline & \multirow{2}{*}{$\begin{array}{c}\text { CRM } 278 \\
\text { mussel }\end{array}$} & \multicolumn{2}{|c|}{ juvenile stage } & \multicolumn{2}{|c|}{$51-58 \mathrm{~mm}$} & \multicolumn{2}{|c|}{$58.5-65.5 \mathrm{~mm}$} & \multicolumn{2}{|c|}{$66-73 \mathrm{~mm}$} \\
\hline & & mussel & shell & mussel & shell & mussel & shell & mussel & shell \\
\hline $\mathrm{Ca}$ & 5.17 & 15.6 & 4.67 & 30.2 & 0.84 & 43.5 & 1.37 & 26.3 & 1.32 \\
\hline $\mathrm{Cu}$ & 4.65 & 15.3 & 11.1 & 39.6 & 26.6 & 15.1 & 25.9 & 38.6 & 29.6 \\
\hline $\mathrm{Fe}$ & 5.04 & 18.4 & 19.2 & 28.4 & 21.2 & 26.6 & 39.5 & 20.3 & 44.8 \\
\hline $\mathrm{Mn}$ & 9.26 & 20.6 & 16.4 & 26.3 & 19.4 & 27.7 & 22.8 & 24.1 & 9.91 \\
\hline $\mathrm{Zn}$ & 3.06 & 20.2 & 57.1 & 38.3 & $*$ & 42.7 & $*$ & 33.3 & $*$ \\
\hline $\mathrm{Al}$ & 21.5 & 22.7 & 103 & 38.5 & 143 & 60.1 & 56.5 & 43.8 & 90.6 \\
\hline $\mathrm{V}$ & 13.0 & 21.8 & 64.5 & 27.8 & 61.9 & 49.0 & 67.7 & 24.7 & 35.4 \\
\hline $\mathrm{Cr}$ & 8.35 & 20.6 & 45.2 & 44.6 & 74.2 & 35.1 & 84.0 & 25.6 & 74.7 \\
\hline Co & 8.85 & 9.94 & 5.37 & 21.0 & 5.13 & 22.0 & 4.39 & 13.9 & 6.94 \\
\hline $\mathrm{Ni}$ & 8.80 & 23.8 & 62.4 & 189 & 16.9 & 30.2 & 13.1 & 16.8 & 11.3 \\
\hline As & 4.38 & 12.9 & 28.6 & 23.7 & 44.5 & 16.5 & 55.2 & 10.5 & 24.4 \\
\hline Mo & 13.6 & 132 & 75.8 & 17.7 & 60.2 & 18.8 & 16.0 & 14.8 & 38.5 \\
\hline $\mathrm{Cd}$ & 8.19 & 36.1 & 11.5 & 27.4 & $*$ & 37.5 & $*$ & 26.2 & $*$ \\
\hline $\mathrm{Pb}$ & 9.77 & 13.5 & 21.5 & 32.5 & 71.4 & 29.0 & 33.9 & 24.4 & 73.8 \\
\hline
\end{tabular}

cal cluster analysis (VARCLUS procedure) was performed separately for shell and soft tissue data in order to derive groups of samples from the raw data set according to their similarity. This analysis was intended to assess the possibility of reducing the number of trace elements to be quantified when biomonitoring using Unio pictorum. The Euclidean distance was selected as the measure of similarity and the clustering algorithm used was the Ward method. The maximum number of clusters was not defined. The dendrograms for both shell and soft tissue were derived using the TREE procedure.

\section{RESULTS}

The coefficients of variation $(\mathrm{CV} \%)$ calculated for the elements quantified in both the mussel tissue CRM 278 and in the shell and soft tissue samples from Lake Maggiore are reported in table 3, where Unio samples are divided by size class. For a comparison, means of metal concentrations in shell and mussel of the 43 samples under investigation are shown in table 2 .

$\mathrm{CV}$ values appear to be the highest in the case of juvenile and adult stage $(51-58 \mathrm{~mm})$ shell samples. Soft tissue variability is comparable to that of the certified samples just for $\mathrm{Ca}$ and $\mathrm{Co}$. For the elements analyzed, the range of data variation in shells was largest for $\mathrm{Al}$ in the juvenile stage and the $51-58 \mathrm{~mm}$ group, for soft tissues it was largest for $\mathrm{Ni}$ in the 51-58 mm group and for Mo in the juvenile stage. If we compare the soft tissue size classes by ranking the element $\mathrm{CVs}$, the Wicoxon signed rank test revealed a significant difference $(p$ $<0.05$, values greater than the critical value of 3.84) in the variability between all the paired size groups, except for the 51-58 and 58.5-65.5 mm samples. For all size classes, the variability resulted significantly different and much greater than in the certified sample.

In the case of shell samples, the variability between all the paired size groups resulted instead not signifi- cantly different according to the Wicoxon test ( $p<0.05$, all values lower than the critical value of 3.84).

The results obtained by the signed rank test mean that element concentration variability in general depend on the shell length just for soft tissues, not for shells, and that sampling variability is significantly different to that of analytical method (CVs of CRM sample). It could be very important to know the concentration variability of different individual groups for two main reasons:

i) the sampling design should include a preliminary analysis to determine the number of samples necessary to ensure a specified level of precision;

ii) this value may be combined with the value of analytical precision (BCR) to obtain an estimate of the "experimental" (sampling + analysis) precision. The use of CV instead of variance plays an important role when datasets are characterized by different units or widely different means.

Table 4 shows the calculated CV\% for the elements investigated in mussel tissue CRM 278 and in shell and soft tissue samples classified by the number of rings.Variability appeared to be higher for most of the elements in soft tissue samples with 4 or 5 rings and in the smallest individuals. Data variation was very large for $\mathrm{Al}$ in shells with no rings or 6 rings, for $\mathrm{Cr}$ in shells with 3 or 5 rings, for $\mathrm{Ni}$ in the soft tissues of individuals with 3 rings and for Mo in the soft tissues of 4-ring or very small mussels. As for size classes, a comparison between paired ring groups by Wicoxon test $(p<0.05)$ revealed that:

i) variability for soft tissues is significantly different and much greater than in the certified sample;

ii) variability of shell is not significantly different.

The signed rank test showed that element concentration variability depend on the age just for soft tissues and just in some pairs (e.g., 4-6, 4-1, 5-1 and 5-3 ring classes), and that sampling variability is significantly different to that of analytical method (CVs of CRM sample). 
Tab. 4. Coefficient of variation (CV\%) calculated from mean and standard deviation for each element quantified in BCR (Community Bureau of Reference) mussel tissue CRM 278 (11 measurements), and mussel shell and tissue samples (4 measurements at least). Unio pictorum mancus samples were divided into classes by number of rings $(<1,3$, $4,5,6) . *$ values not detectable.

\begin{tabular}{|c|c|c|c|c|c|c|c|c|c|c|c|}
\hline \multirow[t]{2}{*}{ Element } & \multirow{2}{*}{$\begin{array}{l}\text { CRM } 278 \\
\text { soft tissues }\end{array}$} & \multicolumn{2}{|c|}{$<1$} & \multicolumn{2}{|c|}{3} & \multicolumn{2}{|c|}{4} & \multicolumn{2}{|c|}{5} & \multicolumn{2}{|c|}{6} \\
\hline & & soft tissue & shell & soft tissue & shell & soft tissue & shell & soft tissue & shell & soft tissue & shell \\
\hline $\mathrm{Ca}$ & 5.17 & 15.6 & 4.67 & 14.6 & 2.34 & 50.5 & 1.26 & 31.8 & 2.10 & 26.2 & 1.55 \\
\hline $\mathrm{Cu}$ & 4.65 & 15.3 & 11.1 & 26.8 & 24.1 & 54.2 & 32.8 & 34.9 & 28.0 & 25.7 & 23.7 \\
\hline $\mathrm{Fe}$ & 5.04 & 18.4 & 19.2 & 20.2 & 32.7 & 23.7 & 22.8 & 26.8 & 34.3 & 16.2 & 49.7 \\
\hline $\mathrm{Mn}$ & 9.26 & 20.6 & 16.4 & 17.6 & 3.27 & 35.3 & 18.6 & 20.4 & 16.4 & 24.0 & 11.5 \\
\hline $\mathrm{Zn}$ & 3.06 & 20.2 & 57.1 & 18.4 & * & 45.7 & * & 30.0 & * & 41.7 & * \\
\hline $\mathrm{Al}$ & 21.5 & 22.7 & 103 & 53.1 & 53.0 & 39.4 & 33.4 & 67.1 & 75.4 & 48.7 & 101 \\
\hline V & 13.0 & 21.8 & 64.5 & 48.4 & 66.1 & 31.4 & * & 47.0 & 82.0 & 39.6 & 49.0 \\
\hline $\mathrm{Cr}$ & 8.35 & 20.6 & 45.2 & 42.6 & 110 & 27.8 & 60.4 & 48.6 & 114 & 39.7 & 58.9 \\
\hline Co & 8.85 & 9.94 & 5.37 & 12.4 & 3.50 & 26.1 & 4.01 & 15.6 & 5.65 & 20.8 & 5.30 \\
\hline $\mathrm{Ni}$ & 8.80 & 23.8 & 62.4 & 158 & 20.7 & 28.6 & 10.9 & 35.3 & 15.2 & 6.78 & 15.8 \\
\hline As & 4.38 & 12.9 & 28.6 & 7.09 & 27.4 & 21.2 & 56.7 & 16.4 & 56.1 & 18.8 & 42.8 \\
\hline Mo & 13.6 & 132 & 75.8 & 10.8 & 53.3 & 20.6 & 142 & 15.5 & 30.6 & 14.6 & 33.3 \\
\hline $\mathrm{Cd}$ & 8.19 & 36.1 & 11.5 & 50.2 & * & 27.5 & * & 31.8 & * & 21.0 & * \\
\hline $\mathrm{Pb}$ & 9.77 & 13.5 & 21.5 & 18.3 & 22.4 & 35.9 & 82.2 & 18.6 & 38.6 & 33.6 & 69.2 \\
\hline
\end{tabular}

If we classify shells either by size class or ring number, weight increases as shell size rises $(8.41,11.34$ and $14.86 \mathrm{~g}$ respectively in the size classes considered and $9.81,10.82,11.03$ and 14.16 for shells with $3,4,5$ and 6 rings respectively). In tables 5 and 6 , the $\mathrm{CV} \%$ is shown for shells grouped by size and by ring class respectively, after multiplication of the element concentrations by the shell weight. In both tables, it can be seen that variability for total content is generally higher than variability for concentration, especially for those elements which have very low concentrations. Therefore, the "weight factor" is characterized by a huge range of values, not proportional to the element concentration, and enlarges the variance of the results. The variability between the paired size classes resulted not significantly different according to the Wicoxon test, except for the pair 51-58 / $58.5-65.5 \mathrm{~mm}(p<0.05)$. For ring classes, variability was significantly different only for 3-5, 3-6 and 4-6 pair classes.

Tab. 5. Coefficient of variation (CV\%) calculated from mean and standard deviation for the total content (concentration $\times$ weight) of each element quantified in shell samples of Unio pictorum mancus as divided into size classes $(51-58 \mathrm{~mm}, 58.5-65.5 \mathrm{~mm}$ and $66-73 \mathrm{~mm}, 9$ replicates at least). Samples at juvenile stage were not weighed. * values not detectable.

\begin{tabular}{lccc} 
Element & \multicolumn{3}{c}{ Size class } \\
\cline { 2 - 4 } & $51-58 \mathrm{~mm}$ & $58.5-65.5 \mathrm{~mm}$ & $66-73 \mathrm{~mm}$ \\
\hline $\mathrm{Ca}$ & 14.3 & 20.3 & 13.9 \\
$\mathrm{Cu}$ & 33.6 & 34.7 & 29.8 \\
$\mathrm{Fe}$ & 16.4 & 36.0 & 52.8 \\
$\mathrm{Mn}$ & 22.9 & 37.3 & 22.7 \\
$\mathrm{Zn}$ & $*$ & $*$ & $*$ \\
$\mathrm{Al}$ & 190 & 76.3 & 104 \\
$\mathrm{~V}$ & 165 & 174 & 208 \\
$\mathrm{Cr}$ & 86.0 & 86.0 & 84 \\
$\mathrm{Co}$ & 13.8 & 21.6 & 14.6 \\
$\mathrm{Ni}$ & 20.4 & 21.3 & 13.7 \\
$\mathrm{As}$ & 46.2 & 61.4 & 21.7 \\
$\mathrm{Mo}$ & 53.4 & 148 & 129 \\
$\mathrm{Cd}$ & $*$ & $*$ & $*$ \\
$\mathrm{~Pb}$ & 70.2 & 36.8 & 87.5 \\
\hline
\end{tabular}

Tab. 6. Coefficient of variation (CV\%) calculated from mean and standard deviation for the total content (concentration $\times$ weight) of each element quantified in shell samples of Unio pictorum mancus as divided into classes by number of rings $(3,4,5,6)$. Samples with less than 1 ring were not weighed. * = values not detectable.

\begin{tabular}{lcccc} 
Element & \multicolumn{4}{c}{ Ring number } \\
\cline { 2 - 5 } & 3 & 4 & 5 & 6 \\
\hline $\mathrm{Ca}$ & 23.2 & 17.7 & 21.3 & 40.9 \\
$\mathrm{Cu}$ & 16.7 & 42.5 & 39.1 & 74.3 \\
$\mathrm{Fe}$ & 29.5 & 22.8 & 45.6 & 78.9 \\
$\mathrm{Mn}$ & 23.4 & 32.0 & 26.7 & 41.6 \\
$\mathrm{Zn}$ & $*$ & $*$ & $*$ & $*$ \\
$\mathrm{Al}$ & 53.8 & 70.6 & 124 & 111 \\
$\mathrm{~V}$ & 101 & $*$ & 222 & 131 \\
$\mathrm{Cr}$ & 121 & 62.6 & 139 & 80.6 \\
$\mathrm{Co}$ & 19.7 & 20.3 & 20.4 & 40.2 \\
$\mathrm{Ni}$ & 27.9 & 25.3 & 15.9 & 35.1 \\
$\mathrm{As}$ & 44.4 & 68.7 & 68.2 & 79.6 \\
$\mathrm{Mo}$ & 75.6 & 139 & 120 & 92.4 \\
$\mathrm{Cd}$ & $*$ & $*$ & $*$ & $*$ \\
$\mathrm{~Pb}$ & 5.01 & 65.4 & 53.3 & 80.6 \\
\hline
\end{tabular}

The shell/soft tissue ratio, as calculated for each measured element (Tab. 7), indicates that partition between shell and soft tissue is roughly the same in the juvenile and adult stages for the following elements: Fe, $\mathrm{Al}, \mathrm{Co}, \mathrm{As}, \mathrm{Pb}$. In general, during the adult stage, the accumulation of $\mathrm{Ca}, \mathrm{Cu}, \mathrm{Mn}, \mathrm{Ni}$ and $\mathrm{Cd} . \mathrm{V}, \mathrm{Cr}$ in shell is lower and that in the soft tissue is not proportionally lower, or the increase in the soft tissue is higher and not proportional to that in the shell. Concentrations of the same order of magnitude were measured in the shell and in the soft tissue for $\mathrm{Co}$ and $\mathrm{Ni}$, while $\mathrm{Ca}$ concentrations were about 10 times greater in the shell (as expected). Concentrations were more than 10-fold higher in soft tissue for Fe, Mn, V, As, and Mo and more than 100 times higher in soft tissue for $\mathrm{Cd}$.

For shells, the correlation of number of rings and length with element concentrations (Tab. 8) was significant (at $p<0.01$ ) for $\mathrm{V}, \mathrm{Cr}$ and Mo (positive coefficient) and (at $p<0.05$ ) for Co (negative coefficient). The cor- 
Tab. 7. Shell/tissue ratio for the mean concentrations of the investigated elements calculated for both the juvenile and the adult stage $(*=$ values not detectable).

\begin{tabular}{lcccccccccccccc}
\hline & $\mathrm{Ca}$ & $\mathrm{Cu}$ & $\mathrm{Fe}$ & $\mathrm{Mn}$ & $\mathrm{Zn}$ & $\mathrm{Al}$ & $\mathrm{V}$ & $\mathrm{Cr}$ & $\mathrm{Co}$ & $\mathrm{Ni}$ & $\mathrm{As}$ & $\mathrm{Mo}$ & $\mathrm{Cd}$ & $\mathrm{Pb}$ \\
\hline juvenile stage & 12.9 & 0.25 & 0.05 & 0.10 & 0.02 & 0.20 & 0.03 & 0.09 & 0.79 & 3.30 & 0.04 & 0.01 & 0.07 & 0.05 \\
adult stage & 6.08 & 0.14 & 0.04 & 0.04 & $*$ & 0.18 & 0.10 & 0.23 & 0.58 & 1.57 & 0.03 & 0.05 & 0.02 & 0.05 \\
\hline
\end{tabular}

Tab. 8. Comparison between the effect of ring number and shell length on element concentrations in a) shell and b) soft tissue. Correlation coefficients $(r)$ and their significance: $*=$ significance at $p<0.05, * *=$ significance at $p<0.01$ levels, n.s. $=$ not significant.

\begin{tabular}{lcccccccccccccc}
\hline & $\mathrm{Ca}$ & $\mathrm{Cu}$ & $\mathrm{Fe}$ & $\mathrm{Mn}$ & $\mathrm{Zn}$ & $\mathrm{Al}$ & $\mathrm{V}$ & $\mathrm{Cr}$ & $\mathrm{Co}$ & $\mathrm{Ni}$ & $\mathrm{As}$ & $\mathrm{Mo}$ & $\mathrm{Cd}$ & $\mathrm{Pb}$ \\
\hline $\begin{array}{l}\text { a) shell } \\
\text { ring number } \\
\text { shell length }\end{array}$ & n.s. & n.s. & n.s. & n.s. & - & n.s. & $0.51^{* *}$ & $0.38^{* *}$ & $-0.31^{*}$ & n.s. & n.s. & $0.52^{* *}$ & - & n.s. \\
$\begin{array}{l}\text { b) soft tissue } \\
\text { ring number } \\
\text { shell length }\end{array}$ & & n.s. & n.s. & n.s. & - & $-0.38^{* *}$ & $0.40^{* *}$ & $0.35^{*}$ & $-0.31^{*}$ & n.s. & n.s. & $0.62^{* *}$ & - & n.s. \\
\hline
\end{tabular}
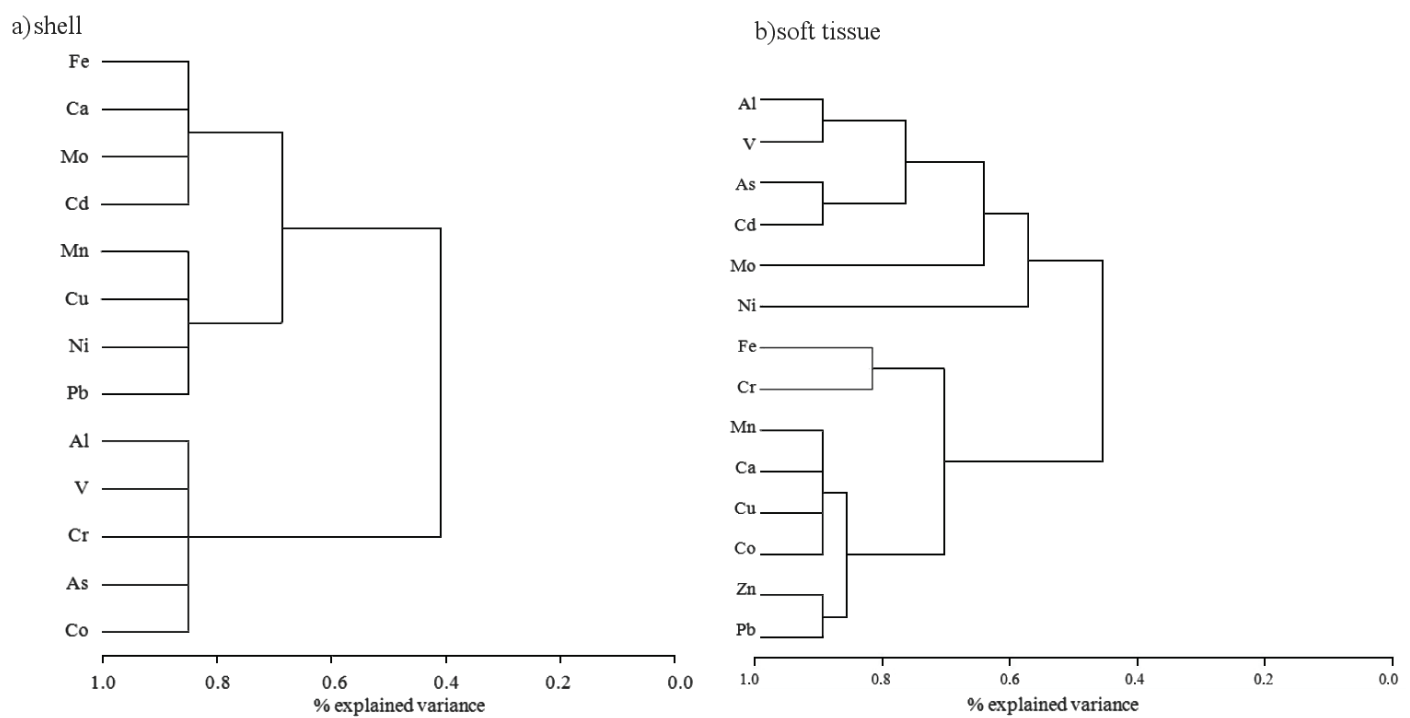

Fig. 2. Horizontal hierarchical tree plot of the metals analyzed in a) shell and b) mussel samples of Unio pictorum mancus.

relation between shell length and $\mathrm{Al}$ was significant at $p$ $<0.01$, with a negative coefficient. On the contrary, for soft tissues, the correlation of the number of rings and/or the shell length with the element concentration was significant only for $\mathrm{Fe}$, with a positive coefficient (at $p<0.01$ ). The regression coefficient between length and concentration was significant (at $p<0.05$ at least) and positive for half the elements, except $\mathrm{Cr}, \mathrm{Ni}, \mathrm{Mo}$ and $\mathrm{Pb}$ (not significant) and $\mathrm{Al}$ and $\mathrm{V}$ (negative values). The correlation with the number of rings was significant only for $\mathrm{Fe}$ and $\mathrm{Mo}$ (at $p<0.01$ and $<0.05$ respectively and positive) and $\mathrm{Ni}$ (significant at $p<0.05$ and negative).

As can be seen in the dendrogram obtained using PROC TREE (Fig. 2), elements in the shell samples can be placed in three groups explaining over $70 \%$ of the variance: i) $\mathrm{Al}, \mathrm{V}, \mathrm{Cr}$, As and $\mathrm{Co}$; ii) $\mathrm{Fe}, \mathrm{Ca}, \mathrm{Mo}, \mathrm{Cd}$; iii) $\mathrm{Mn}, \mathrm{Cu}, \mathrm{Ni}$ and $\mathrm{Pb}$. $\mathrm{Zn}$ was not included because all measured values were below the instrument's detection limit. According to the dendrogram for soft tissue samples (Fig. 2b), the elements can be divided into four groups, which explain over $70 \%$ of the variance: i) $\mathrm{Al}$, $\mathrm{V}$, As, $\mathrm{Cd}$ and $\mathrm{Mo}$; ii) Ni only; iii) $\mathrm{Fe}$ and $\mathrm{Cr}$; iv) $\mathrm{Mn}$, $\mathrm{Ca}, \mathrm{Cu}, \mathrm{Co}, \mathrm{Zn}$ and $\mathrm{Pb}$.

\section{DISCUSSION AND CONCLUSIONS}

Notwithstanding the trueness and precision of the analytical method (Tabs 2 and 3), whether the Unio samples were divided by size or by number of rings, in general the variability was significantly larger than it was for the certified mussel sample (Tabs 3 and 4). By selecting the same location and collection period for adult specimens, the study was able to reduce the influence of seasonal variations and trophic level on element concentrations (Ravera et al. 2007b; Ravera et al. 2009). The minimum number of collected samples was 9 and 4 according the partition in size classes and the ring classes respectively. The accumulation was influenced not only by mussel size (Ravera et al. 2003b), but also by growth rate and the accumulation rates (Beone 
et al. 2003; Ravera et al. 2009), the physiological needs of each specimen (Ravera et al. 2007a) and the interactions among these various elements (Daka et al. 2006). For example, Unio can modify its metabolism depending on the temperature, like all heterotherm animals, and depending on oxygen availability: it can survive for a long period of time buried in hypoxic or anoxic sediments by reducing its metabolic rate, living anaerobically and producing succinic acid as a by-product (Campanella et al. 2005). Its metabolic rate can increase heavy metal accumulation and the acidity can release the heavy metals bound to the organic matter of the shell and to calcium phosphate granules (Bauer \& Wächtler 2001). In tables 5 and 6, CVs of total content (concentration $\times$ weight) in shells appear very heterogeneous among the various size and ring classes. In general, there is a negative relationship between means and variances, which results in higher CVs for metals with lower means. This is observed in the present study, but the use of $\mathrm{CV}$ instead of variance could be crucial to compare datasets characterized by different units (i.e., $\mathrm{Ca}$ ) or widely different means and variances (e.g., Co, $\mathrm{Cu}$ and $\mathrm{Zn}$ ). The sign test on the obtained size or ring classes after having ranked the element CVs, confirms a limited variability between paired groups.

In general, soft tissues at the juvenile stage exhibit low $\mathrm{CV} \%$ values, except for Mo (Tab. 3). If we consider the burrowing lifestyle of Unio in the early adult stage, the variability of juvenile shells can be explained not only by the total concentration, but also by the available concentration in the sediments, which is strictly connected to changes in the depth of the overlying water column and, correspondingly, to the redox status (Fox \& Doner 2003). In fact, the Lake Maggiore sampling station used for this study frequently shows the combined effects of a decrease in water level and a gently sloping coastal zone (Ravera et al. 2009). In a previous work, Ravera et al. (2003b) found no relationship between metal concentrations in the soft tissues and in the shell. This is because, as reported by Ravera et al. (2007a), the shell composition represents the situation throughout the life of the specimen, while the chemical composition of the soft tissue only reflects the recent environment situation. This also provided a rationale for the coexistence of low and high variability of the same elements in the shell and the soft tissue, which was not only observed in the smallest individuals.

It is commonly accepted that calcium is the most abundant metal in both shells and soft tissues: it has a key role in the physiology of bivalves, as the main component of the shell and the calcium carbonate granules in the soft tissues (Förstner \& Wittmann 1983; Byrne 2000; Byrne \& Vesk 2000). Furthermore, its low affinity with chelating substances increases its availability to the organism. The result is that the calcium concentration in the aquatic environment is reflected in the amount accumulated by Unio specimens. In this study, we found that calcium was the main element in the shell (Tab. 2), followed by $\mathrm{Mn}, \mathrm{Al}, \mathrm{Fe}, \mathrm{Ni}$ and $\mathrm{Cu}$ (from highest to lowest concentration). However, as can be seen in table 7, only $\mathrm{Ca}$ and $\mathrm{Ni}$ are stored in the shell. Nyström et al. (1996) pointed out the well-known capacity of Unio to accumulate manganese in its shell by binding it to organic matter encircling aragonite crystals in the nacreous layer, Ravera et al. (2003b) highlighted a similar chemical behavior in iron. It is plausible that $\mathrm{Mn}, \mathrm{Al}, \mathrm{Fe}$ and $\mathrm{Cu}$ are mostly bound up in the carbonate granules in the specimens investigated. Aluminum does not play a physiological role and is typically present in the sediment compartment. The probable reason for its high concentration in shells and soft tissues (ranging from 7 to $140 \mathrm{mg} \mathrm{kg}^{-1}$ in shells and approximately 5 times more concentrated in soft tissues) is that divalent and trivalent nonessential trace metals should follow the same metabolic pathway as calcium from the water to the mussel's gills (Markich \& Jeffree 1994). $\mathrm{Ni}$ and $\mathrm{Cu}$ are also accumulated (in shells and soft tissues respectively). However, our data highlight the fact that the accumulation of $\mathrm{Ca}, \mathrm{Ni}$ and $\mathrm{Cu}$ in shells is not proportional to size, although $\mathrm{Al}$ accumulation decreases significantly with length (Tab. 8). In soft tissue, $\mathrm{Ca}$ accumulation clearly tends to increase with mussel size, whereas Al accumulation decreases with size. The findings of Markich \& Jeffree may also explain the data concerning $\mathrm{Cu}$ and $\mathrm{Zn}$, which are essential only in small amounts. As these elements are more concentrated in soft tissues than in the shell (Tab. 7), they are almost certainly detoxified by Unio as previously discussed (Ravera et al. 2003a), for the most part without being transferred to the mantle and consequently to the shell. The remaining elements were represented more in the soft tissue (Tab. 7) as well. Our observation concerning distribution between the shell and the soft tissue partly contradicted what has been reported in the literature (Ravera et al. 2003a). These results may depend on the more or less marked ability to discriminate between elements based on the physiological needs of individuals, which should be considered in the environmental context. Unfortunately, we do not have any data concerning concentration in the water and sediments. It is plausible, however, that these elements could be more concentrated in the mussels than in the water, and in some cases more than in the sediment, due to the filtering and accumulating nature of Unio.

It is interesting to note that $\mathrm{V}, \mathrm{Cr}$ and $\mathrm{Mo}$, which are essential elements (Yarsan et al. 2007), tend to accumulate in the shell progressively over the years (Tab. 8), whereas $\mathrm{Co}$ and $\mathrm{Al}$ are "diluted" during growth, as if the growth rate is faster than the accumulation rate (Boyden 1977) or as if they are absorbed mainly during the juvenile stage, (from the sediment), with the absorption rate steadily decreasing during the adult stage. The results obtained by Koretsky et al. (2006), Gimeno-Garcìa et al. (1996) and Gao et al. (2007) confirm that $\mathrm{Co}$ and $\mathrm{Al}$ 
are more prevalent in sediment than in the water in lentic environments.

The relationship between growth and accumulation in both the soft tissues and in the shell is similarly based on a positive correlation in the case of Mo only and on a negative correlation in the case of $\mathrm{Al}$ only. Most elements in the soft tissues of mussels are present in greater concentration as the mussels increase in size and age, with a significant correlation. In the case of $\mathrm{Al}$ and $\mathrm{V}$, we observed a "dilution" by the larger mass. Our results concerning $\mathrm{Mn}, \mathrm{Fe}, \mathrm{Zn}$ and $\mathrm{Ca}$ are in agreement with the study realized by Ravera et al. (2003b). The accumulation of $\mathrm{Cd}$ in soft tissue, due to repeated biological detoxification by metallothioneins and the glutathione system (Belcheva et al. 2006), causes the sizedependent cadmium concentration observed. For $\mathrm{Cu}, \mathrm{Fe}$ and $\mathrm{Zn}$, which are characterized by an analogous increment, the sequestration and toxicity limitation mechanism is similar (Cosson 2000).

The size correlation was not clear for the other elements investigated. These could be due to mutual independence between the variables. In general, shell length appears to be more strongly linked to element concentrations than the specimen age. As stated by Kwan et al. (2003), the independence of element concentrations from size classes may not be real, but could be smaller than the smallest one of the size class immediately above. According to our results, a size class may contain animals of different ages, reflecting the environmental conditions of different years. As reported by Negus (1966), Peterson \& Beal (1989) and Adam (1990), bivalve growth can depend on population density, site temperature, organic matter availability and the alternation between wet and dry periods. Our sampling station was affected by all of these factors except the first, and especially by the last. The number of rings, if correctly determined, corresponds to the age (Negus 1966). Therefore, if growth is not homogeneous for all the samples investigated, the number of rings could probably be used to highlight differences in the aquatic pollution of the environments over the recent past. For the older specimens, these differences could be due to higher bioavailable concentrations of the elements during their first year of life or a higher capacity for accumulation due to metabolic modifications in their last year of life. As it can be seen in the dendrogram obtained by PROC TREE (Fig. 2), elements in the shell can be placed into three groups that explain more than $70 \%$ of the variance: i) $\mathrm{Al}, \mathrm{V}, \mathrm{Cr}, \mathrm{As}$ and $\mathrm{Co}$; ii) $\mathrm{Fe}, \mathrm{Ca}$, $\mathrm{Mo}, \mathrm{Cd}$; iii) $\mathrm{Mn}, \mathrm{Cu}, \mathrm{Ni}$ and $\mathrm{Pb}$. $\mathrm{Zn}$ was not included because all measured values were below the instrument's detection limit.

According to the dendrogram for soft tissue (Fig. $2 b$ ), the elements can be placed into four groups, that explain more than $70 \%$ of the variance: i) $\mathrm{Al}, \mathrm{V}, \mathrm{As}, \mathrm{Cd}$ and $\mathrm{Mo}$; ii) Ni only; iii) $\mathrm{Fe}$ and $\mathrm{Cr}$; iv) $\mathrm{Mn}, \mathrm{Ca}, \mathrm{Cu}, \mathrm{Co}$, $\mathrm{Zn}$ and $\mathrm{Pb}$.
Three factors influence metal specificity in vivo:

1) differences in metal affinity;

2) differences in intracellular metal concentrations (for example, presence of certain uptake or efflux systems);

3) coordination geometry preferences of various metals/ability to trigger the desired conformational change (Harvie et al. 2006; Rensing 2005; Dutta et al. 2006; Liu et al. 2006).

In 2001, Markich confirmed that extracellular granules are the main deposition sites for $\mathrm{Mn}, \mathrm{Co}, \mathrm{Cu}, \mathrm{Zn}$ and $\mathrm{Pb}$ and that hard and borderline metals, such as $\mathrm{Mn}$, Co and $\mathrm{Zn}$, appear to have a higher affinity for these granules. In the case of $\mathrm{Pb}$, we know that the transporters responsible for zinc uptake and efflux are also responsible for transporting other metal ions, such as $\mathrm{Pb}$ (II) (Rensing 2007).

Cr (III) is less mobile and less toxic and usually binds to organic matter in soil and in aquatic environment (Shanker 2008). The same behaviour is observed in Fe (Ravera et al. 2003). These elements are classified as hard and borderline metals and probably behave similarly to other hard metals as regards extracellular granules.

The elements $\mathrm{V}, \mathrm{Cd}$ and As are frequently associated with the metallothionein (MT) system. MT concentrations were significantly correlated with both total and soluble concentrations of V (Amiard 2009). Induced MTs can bind nonessential metals (including $\mathrm{Cd}$ ), reducing their potential toxicity (Roesijadi 1992, 1996; Zaroogian \& Jackim 2000).

In the mussel Perna viridis, $\mathrm{Cd}$ is a strong MT inducer, as reflected by MT concentrations (Shi \& Wang 2005). Metallothionein levels are usually correlated with cadmium levels (Geffard et al. 2002); in some cases exposure to cadmium and the subsequent induction of metallothionein-like proteins affected cadmium uptake (Blackmore \& Wang 2002).

Arsenite is extremely thiol-reactive. Metallothioneins are thought to have a protective effect against arsenic toxicity and may be responsible, at least in part, for self-induced tolerance (Shanker 2008). Nikel ions have a high affinity for cysteine (Costa et al. 1994) and MT induction by $\mathrm{Ni}$ has been reported in the cod Eleginus navaga (Eriksen et al. 1990). However, although MT induction has been demonstrated in the copepod Tigriopus brevicornis after exposure to $\mathrm{Ni}$, this element was far from the most potent of a series of metals tested in the same set of experiments (Barka et al. 2001).

The correlation values obtained from a cluster analysis of various elements is due to differential binding of metals to ligands on the surface of detoxification system. Hard metals have a high affinity with oxygen donor ligands (phosphate is the major anion in granules), whereas soft metals have high affinity to sulphur or nitrogen donor ligands (thiol groups or metallothioneins). 
The clustering pattern of elements is less distinct in the soft tissues of mussels than in shell. The different clustering pattern in shell probably results from the different chemical processes involved and from its characteristics as a storage matrix for toxic metals (Walsh et al. 1995). Moreover, the shells of long-living, slowgrowing mussel species could serve as records of longterm variation (e.g., on an interannual scale) (Gillikin 2005; Vander Putten 2000; Lazareth 2003). In fact, we found that heavy metal accumulation in shells was not correlated with that in soft tissues (Yap et al. 2010).

The distinct difference between the shells and the various soft tissues in most molluscs may be due to the fact that some trace metals are incorporated into the shells of the bivalve through substitution of the calcium ion in the crystalline phase of the shell or are associated with the organic matrix of the shell (Foster \& Chacko 1995; Yap et al. 2003a). The metals could be distributed through the various soft tissues before being biodeposited in the shell (Yap et al. 2003b). Shell composition is closely related to chemical mineralogy (which involves metals accumulated from the environment); this may be one of the reasons why metal concentrations in the shell tended to be similar to the concentrations in the organism's environment.

\section{REFERENCES}

Adam, M.E. 1990. Shell growth in some Nile Bivalves. J.Moll. Stud., 56: 301-308.

Adriano, D.C. 2001. Trace elements in terrestrial environment; biogeochemistry, bioavailability and risks of metals. Springer, New York, USA: 867 pp.

Ambrosetti, W., L. Barbanti, R. Mosello \& A. Pugnetti. 1992. Limnological studies on the deep southern alpine lakes Maggiore, Lugano, Como, Iseo and Garda. In: Guilizzoni, P. Tartari, G. \& G. Giussani (Eds), Limnology in Italy. Mem Ist. ital. Idrobiol., 50: 117-140.

Amiard, J.C., R. Journel \& H. Bacheley. 2008. Influence of field and experimental exposure of mussels (Mytilus sp.) to nichel and vanadium on metallothionein concentration. Comparative Biochemistry and Physiology, Part C, 147: 378-385.

Barka, S., J.F. Pavillon \& J.C. Amiard. 2001. Influence of different essential and non-essential metals on MTLP levels in the Copepod Tigriopus brevicornis. Comp. Biochem. Physiol., 128C: 479-493.

Bauer, G. \& K. Wächtler. 2001. Ecology and evolution of the freshwaters mussels Unionidae. Springer-Verlag, Berlin Heidelberg, Germany.

Belcheva, N.N., M. Zakhartsev, A.V. Silina, E.N. Slinko \& V.P. Chelomin. 2006. Relationship between shell weight and cadmium content in whole digestive gland of the Japanese scallop Patinopecten yessoensis (Jay). Mar. Environ. Res., 61: 396-409.

Beone, G.M. \& O. Ravera. 2003. Vantaggi e limiti del monitoraggio ambientale mediante l'analisi chimica dei Lamellibranchi. Studi Trent. Sci.-Nat. Acta Biol., 78: 79-84.

Blackmore, G., \& W.-X.Wang. 2002. Uptake and efflux of Cd and $\mathrm{Zn}$ by the green mussel Perna viridis after metal preexposure. Environ. Sci. Technol., 36, 989-995.

Boyden, C.R. 1977. Effect of size upon metal content of shellfish. J. Mar. Bio. Assoc. U.K., 57: 675-714.

Byrne, M. \& P.A. Vesk. 2000. Element composition of mantle tissue granules in Hyridella depressa (Unionida) from the Hawkesbury - Nepean River system, Australia: influence from catchment chemistry. Aust. J. Mar. Freshwat. Res., 51: 183-192.

Byrne, M. 2000. Calcium concretions in the interstitial tissues of the Australian freshwater mussel Hyridella depressa (Hyriidae). In: E.M. Harper, J.D. Taylor \& J.A. Crame (Eds), The Evolutionary Biology of the Bivalvia. Geological Society, London, Special Publications, 177: 329-337.

Campanella, L., T. Gatta \& O. Ravera. 2005. Relationship between anti-oxidant capacity and manganese accumulation in the soft tissues of two freshwater molluscs: Unio pictorum mancus (Lamellibranchia, Unionidae) and $\mathrm{Vi}$ viparus ater (Gastropoda, Prosobranchia). J. Limnol., 64: 153-158.

Cosson, P. 2000. Bivalve metallothionein as a biomarker of aquatic ecosystem pollution by trace metals: limits and perspectives. Cell. Mol. Biol., 46: 295-309.

Costa, M., Z. Zhuang, X. Huang, S. Cosentino, C.B. Klein, K. Salnikov. 1994. Molecular mechanisms of nickel carcinogenesis. Sci. Total Environ., 148, 191-199.

Daka, E., S.J. Hawkins. 2006. Interactive effects of copper, cadmium and lead on zinc accumulation in the gastropod mollusc Littorina saxatilis. Water Air Soil Pollut., 171: 19-28.

Dutta, S.J., J. Liu, Z. Hou \& B. Mitra. 2006. Conserved Asp714 in transmembrane segment 8 of the ZntA subgroup of P1B-type ATPases is a metal-binding residue. Biochemistry, 45: 5923-5931.

Eriksen, K.D.H., T. Andersen \& J. Stenersen. 1990. Iso-metallothionein in cod induced by cadmium, zinc and nickel. Proc. 12 $2^{\text {th }}$ Annual Conference on Physiological and Biochemical Approaches to the Toxicological Assessment of Environmental Pollution, Utrecht, The Netherland.

Forstner, U. \& G.T.W. Wittmann. 1983. Metal Pollution in the aquatic environment. Springer-Verlag, Berlin: 486 pp.

Foster, P. \& J. Chacko. 1995. Minor and trace elements in the shell of Patella vulgata (L.). Marine Environmental Research, 40: 55-76.

Fox, P.M. \& H.E. Doner. 2003. Accumulation, release, and solubility of arsenic, molybdenum, and vanadium in wetland sediments. J. Environ. Qual., 32: 2428-2435.

Gao, Y., M. Leermakers, M. Elskens, G. Billon, B. Ouddane, J-C. Fischer \& W. Baeyens. 2007. High resolution profiles of thallium, manganese and iron assessed by DET and DGT techniques in riverine sediment pore waters. Sci. Tot. Environ., 373: 526-533.

Geffard, A., J.C. Amiard \& C. Amiard-Triquet. 2002. Kinetics of metal elimination in oysters from a contaminated estuary. Comp. Biochem. Physiol., C 131: 281-293.

Gillikin, D.P., F. Dehairs, W. Baeyens, J. Navez, A. Lorrain \& L. André. 2005. Inter- and intra-annual variations of $\mathrm{Pb} / \mathrm{Ca}$ ratios in clam shells (Mercenaria mercenaria): A record of anthropogenic lead pollution? Mar. Pollut. Bull., 50: 1530-1540.

Gimeno-Garcìa, E., V. Andrei \& R. Boluda. 1996. Heavy metals incidence in the application of inorganic fertilizers and pesticides to rice farming soils. Environ. Pollut., 92: 19-25.

Grefsrud, E. \& Ø. Strand. 2006. Comparison of shell strength in wild and cultured scallops (Pecten maximus). Aquaculture, 251: 306-313.

Gundacker, C. 2000. Comparison of heavy metal bioaccumulation in freshwater molluscs of urban river habitats in $\mathrm{Vi}$ enna. Environ. Pollut., 110: 61-71.

Harvie, D.R., C. Andreini, G. Cavallaro, W. Meng, B.A. Connolly, K.I. Yoshida, Y. Fujita, C.R. Harwood, D.S. Radford, S. Tottey, J.S. Cavet \& N.J. Robinson. 2006. Predicting metals sensed by ArsR-SmtB repressors: allosteric interference by a non-effector metal. Mol. Microbiol., 59: 1341-1356.

Kilada, R.W., D. Roddick \& K. Mombourquette. 2007. Age determination, validation, growth and minimum size of sexual maturity of the Greenland smoothcockle (Serripes groenlandicus, Bruguiere, 1789) in eastern Canada. J. Shellfish Res., 26: 443-450. 
Koretsky, C.M., J.R. Haas, D. Miller \& N.T. Ndenga. 2006. Seasonal variations in pore water and sediment geochemistry of littoral lake sediments (Asylum Lake, MI, USA). Geochem. Trans., 7: 11 .

Kwan, K.H.M., H.M. Chan \& Y. De Lafontaine. 2003. Metal contamination in zebra mussels (Dreissena polymorpha) along the St. Lawrence River. Environ. Monit. Assess., 88: 193-219.

Lau, S., M. Mohamed, A. Tan Chi Yen \& S. Su'ut. 1998. Accumulation of heavy metals in freshwater molluscs. Sci. Tot. Environ., 214: 113-121.

Lazareth, C.E., E. Vander Putten, L. André \& F. Dehairs. 2003. High-resolution trace element profiles in shells of the mangrove bivalve Isognomon ephippium: a record of environmental spatio-temporal variations? East Coast Shelf Sci., 57: 1103-1114.

Liu, J., S.J. Dutta, A.J. Stemmler \& B. Mitra. 2006. Metalbinding affinity of the transmembrane site in ZntA: implications for metal selectivity. Biochemistry, 45: 763-772.

Markich, S.J., P.L. Brown \& R.A. Jeffree. 2001. Divalent metal accumulation in freshwater bivalves: an inverse relationship with metal phosphate solubility. Sci. Total Environ., 275: 27-41

Mason, A.Z. \& K.D. Jenkins. 1995. Metal detoxification in aquatic organisms. In: A. Tessier \& D.R. Turner (Eds), Metal speciation and bioavailability in aquatic systems. IUPAC. John Wiley, New York \& Sons Ltd: 479-608.

Metcalfe-Smith, J.L., R.H. Green \& L.C. Grapentine. 1996. Influence of biological factors on concentrations of metals in the tissues of freshwater mussels (Elliptio complanata and Lampsilis radiata radiata) from the St. Lawrence River. Can. J. Fish. Aquat. Sci., 53: 205-219.

Negus, C.L. 1966. A quantitative study of growth and production of unionid mussels in the river Thames at reading. $J$. Anim. Ecol., 35: 513-532.

Nielsen, F.A. 2000. Evolutionary events culminating in specific minerals becoming essential for life. Eur. J. Nut., 39: 62-66.

Nyström, J., E. Dunca, H. Mutvei \& U. Lindh. 1996. Environmental history as reflected by freshwater pearl mussels in the River Vramsån, Southern Sweden. Ambio, 25: 350-355.

Patzner, R.A. \& D. Müller. 2001. Effects of eutrophication on Unionids. In: G. Bauer \& K. Watchtler (Eds), Ecology and evolution of freshwater mussels Unionoida. SpringerVerlag, Berlin. Ecological Studies, 145: 327-335.

Peterson, C.H. \& B.F. Beal. 1989. Bivalve growth and higher order interactions: importance of density, site, and time. Ecology, 70: 1390-1404.

Pitts, L.C., \& G.T.Wallace. 1994. Lead deposition in the shell of the bivalve, Mya arenaria: an indicator of dissolved lead in seawater. Estuarine, Coastal and Shelf Science, 39: 93-104.

Ravera, O. \& A.R. Sprocati. 1997. Population dynamics, production, assimilation and respiration of two fresh water mussels: Unio mancus, Zhadin and Anodonta cygnea Lam. Mem. Ist. ital. Idrobiol., 56: 113-130.

Ravera, O., A. Frediani \& N. Riccardi. 2007a. Seasonal variations in population dynamics and biomass of two Unio pictorum mancus (Mollusca, Unionidae) populations from two lakes of different trophic state. J. Limnol., 66: 15-27.

Ravera, O., G.M. Beone, R. Cenci \& P. Lodigiani. 2003b. Metal concentrations in Unio pictorum mancus (Mollusca, Lamellibranchia) from 12 Northern Italian lakes in relation to their trophic level. J. Limnol., 62: 121-138.

Ravera, O., G.M. Beone, P.R. Trincherini \& N. Riccardi. 2007b. Seasonal variations in metal content of two Unio pictorum mancus (Mollusca, Unionidae) populations from two lakes of different trophic state. J. Limnol., 66: 28-39.

Ravera, O., P.R. Trincherini, G.M. Beone \& B. Maiolini. 2005. The trend from 1934 to 2001 of metal concentrations in bivalve shells (Unio pictorum) from two small lakes: Lake Levico and Lake Caldonazzo (Trento Province, Northern Italy). J. Limnol., 64: 113-118.

Ravera, O., G.M. Beone, M.C. Fontanella, N. Riccardi \& I. Cattani. 2009. Comparison between the mercury contamination in populations of Unio pictorum mancus (Mollusca, Bivalvia) from two lakes of different trophic state: the oligo-mesotrophic Lake Maggiore and the eutrophic Lake Candia. J. Limnol., 68: 359-367.

Ravera, O., R. Cenci, G.M. Beone, M. Dantas \& P. Lodigiani. 2003a. Trace element concentrations in freshwater mussels and macrophytes as related to those in their environment. J. Limnol., 62: 61-70.

Rensing, C. 2005. Form and function in metal-dependent transcriptional regulation: dawn of the enlightenment. $J$. Bacteriol., 187: 3909-3912.

Rensing, C. \& B. Mitra. 2007. Zinc, Cadmium, and Lead resistance and homeostasis. Microbiol. Monogr., 6: 322-341

Roesijadi, G. 1992. Metallothioneins in metal regulation and toxicity in aquatic animals. Aquat. Toxicol., 22: 81-114.

Roesijadi, G. 1996. Metallothionein and its role in toxic metal regulation. Comp. Biochem. Physiol., C 113: 117-123.

S.A.S. Institute. 1996. SAS/STAT user's guide. Version 6, vols. 1 and 2, 4th ed., SAS Inst., Cary, NC.

Shanker, A.K. 2008. Mode of action and toxicity of trace elements. In: M.N.V. Prasad (Ed.), Trace elements as contaminants and nutrients: consequences in ecosystems and human health. University of Hyderbad John Wiley \& Sons, Inc.: 523-550.

Shi, D.L., W.-X. Wang. 2005. Uptake of aqueous and dietary metals by mussel Perna viridis with different $\mathrm{Cd}$ exposure histories. Environ. Sci. Technol., 39: 9363-9369.

Swift, R.S. 1989. Molecular weight, size, shape, and charge characteristics of humic substances: Some basic considerations. In: M.H.B. Hayes, P. McCarthy, R.L. Malcolm and R.S. Swift (Eds), Humic substances: II. John Wiley \& Sons, New York: 449.465.

Vander Putten, E., F. Dehairs, E. Keppens \& W. Baeyens. 2000. High resolution distribution of trace elements in the calcite shell layer of modern mytilus edulis: environmental and biological controls. Geochim. Cosmochim. Acta, 64: 997-1011.

Walsh, K., R.H. Dunstan \& R.N. Murdoch. 1995. Differential bioaccumulation of heavy metals and organopollutants in the soft tissue and shell of the marine gastropod, Austrocochlea constricta. Archives of Environmental Contamination and Toxicology, 28: 35-39.

Yap, C.K., F.B. Edward \& S.G. Tan. 2010. Similarities and differences of metal distributions in the tissues of molluscs by using multivariate analyses. Environ. Monit. Assess., 165: 39-53.

Yap, C.K., A. Ismail \& S.G. Tan. 2003a. Different soft tissues of the green-lipped mussel Perna viridis (L.). as biomonitoring agent of copper: Field and laboratory studies. Malaysian Applied Biology, 32(2): 9-18.

Yap, C.K., A. Ismail, S.G. Tan \& I. Abdul Rahim. 2003b. Can the shell of the green-lipped mussel Perna viridis from the west coast of Peninsular Malaysia be a potential biomonitoring material for $\mathrm{Cd}, \mathrm{Pb}$ and $\mathrm{Zn}$ ? Estuarine, Coastal and Shelf Science, 57: 623-630.

Yarsan, E., R. Baskaya, A. Yildiz, L. Altintas \& S. Yesilot. 2007. Copper, Lead, Cadmium and Mercury concentrations in the mussel Elliptio. Bull. Environ. Contam. Toxicol., 79: 218-220.

Zaroogian, G. \& E. Jackim. 2000. In vivo metallothionein and glutathione status in an acute response to cadmium in Mercenaria mercenaria brown cells. Comp. Biochem. Physiol., C 127: 251-261.

Received: February 2011

Accepted: May 2011 